\title{
The prognostication of development of respiratory tract bacterial diseases for children of early age
}

\author{
H. O. Lezhenko*A,D,F, A. V. Abramov' ${ }^{\mathrm{C}}$, H. V. Krainia ${ }^{\mathrm{B}, \mathrm{C}, \mathrm{D}}$
}

Zaporizhzhia State Medical University, Ukraine

A - research concept and design; B - collection and/or assembly of data; C - data analysis and interpretation; D - writing the article;

$\mathrm{E}$ - critical revision of the article; $\mathrm{F}$ - final approval of the article

The purpose of this study was definition of influence of the modified factors in development of acute pneumonia in children of early age and development of the method of prognostication of disease development.

Materials and methods. 89 children of early age with acute bronchopulmonary pathology whose average age was $1.3 \pm 0.2$ years ( 47 children with acute bacterial bronchits and 42 children with acute community-acquired pneumonia) were examined. Also we tested the level of 25 -hydroxyvitamin D $(25(\mathrm{OH}) \mathrm{D})$, hBPI, cathelicidin LL-37, lactoferrin in blood serum with the help of immunoenzymometric analysis. The significant factors that are most associated with the development of acute pneumonia were revealed using factor analysis. For prognostication of probability of development of an acute pneumonia the equation of logistic regression was used. Determination of quality of the received model of prognostication was conducted by means of the ROC analysis and index of AUC. For assessment of the discriminating ability of model the Gini index was calculated.

Results. By results of conducted factor analysis 5 significant factors determining the main part of predictors of development of an acute pneumonia in children of early age, patients with acute inflammatory bronchopulmonary pathology were allocated. The conducted correlation analysis of variables revealed existence of interrelations between prenatal, anamnestic and immune factors which entered further mathematical model of probability of development of an acute pneumonia in children of early age. The statistical importance of the created model was confirmed by Omnibus Test, the diagnostic information content was estimated according to a ROC curve that confirmed high quality of model.

Conclusion. On the basis of the conducted factor analysis the most priority predictors of development of an acute pneumonia in children of early age with acute bronchopulmonary pathology who were further included to the mathematical prognostic model of probability of development of the specified disease were allocated.

\section{Прогнозування розвитку бактеріальних захворювань органів дихання в дітей раннього віку}

\section{Г. О. Аеженко, А. В. Абрамов, Г. В. Крайня}

Мета роботи - визначення впливу модифікованих фракторів у розвитку гострої пневмонії в дітей раннього віку та розроблення методу прогнозування розвитку захворювання.

Матеріали та методи. Обстежили 89 дітей раннього віку з гострою бронхолегеневою патологією, середній вік яких становив 1,3 0 0,2 року (47 дітей, які хворі на гострий бактеріальний бронхіт, і 42 дітей, які хворі на гостру позалікарняну пневмонію). За допомогою імуноферментного аналізу досліджували вміст у сироватці крові 25-гідроксивітаміну Д (25(OH) D), hBPI, кателіцидину LL-37, лактоферину. За допомогою фракторного аналізу виявили значущі фактори, що найбільше пов'язані з розвитком гострої пневмонії. Для прогнозування ймовірності розвитку гострої пневмонії використовували рівняння логістичної регресії. Якість отриманої моделі прогнозування визначали за допомогою ROC-аналізу та показника AUC. Для оцінювання дискримінуючої здатності моделі розраховували індекс Gini.

Результати. За результатами фракторного аналізу виділили 5 значущих фракторів, що детермінують основну частину предикторів розвитку гострої пневмонії в дітей раннього віку, які хворі на гостру запальну бронхолегеневу патологію. Кореляційний аналіз змінних показав наявність взаємозв'язків між пренатальними, анамнестичними та імунними факторами, які надалі ввійшли до математичної моделі ймовірності розвитку гострої пневмонії в дітей раннього віку. Статистичну значущість створеної моделі підтверджено Omnibus Test, діагностична інформативність оцінена за даними ROC-кривої, яка підтвердила хорошу якість моделі.

Висновки. На підставі фракторного аналізу визначили пріоритетні предиктори розвитку гострої пневмонії в дітей раннього віку, які хворі на гостру запальну бронхолегеневу патологію, що надалі ввійшли до математичної моделі прогнозу ймовірності розвитку цього захворювання.
Key words: inflammatory diseases of the bronchopulmonary system, pneumonia, statistical factor analysis, infants, logistic models.

Pathologia 2019; 16 (2), 231-237 DOI: 10.14739/2310-1237. 2019.2.177169

*E-mail: Genalezh@gmail.com

Кнючові слова: запальні захворювання бронхолегеневої системи, пневмонія, факторний аналіз, Аіти раннього віку, могістична модель.

Патологія. - 2019. T. 16, № 2(46). C. 231-237

\section{Прогнозирование развития бактериальных заболеваний органов дыхания у детей раннего возраста}

\section{Г. А. Аеженко, А. В. Абрамов, А. В. Крайняя}

Цель работы - определение влияния модифицированных фракторов в развитии острой пневмонии у детей раннего возраста и разработка метода прогнозирования развития заболевания. 
Ключевые слова: воспалительные заболевания бронхолегочной системы, пневмония, факторный анализ, Аети раннего возраста, могистическая модель.

Патология. - 2019. T. 16, № 2(46). -

C. 231-237

Материалы и методы. Обследовали 89 детей раннего возраста с острой бронхолегочной патологией, средний возраст которых составил $1,3 \pm 0,2$ года (47 детей с острым бактериальным бронхитом и 42 детей с острой внебольничной пневмонией). С помощью иммуноферментного анализа исследовали содержание в сыворотке крови 25-гидроксивитамина Д (25(OH)D), hBPI, кателицидина LL-37, лактофреррина. С помощью факторного анализа установлены значимые факторы, которые в наибольшей степени связаны с развитием острой пневмонии. Для прогнозирования вероятности развития острой пневмонии было использовано уравнение логистической регрессии. Определение качества полученной модели прогнозирования проводили с помощью ROC-анализа и показателя AUC. Для оценки дискриминирующей способности модели рассчитывался индекс Gini.

Результаты. В результате факторного анализа выделили 5 значимых факторов, детерминирующих основную часть предикторов развития острой пневмонии у детей раннего возраста, больных острой воспалительной бронхолегочной патологией. Корреляционный анализ переменных показал наличие взаимосвязей между пренатальными, анамнестическими и иммунными факторами, которые в дальнейшем вошли в математическую модель вероятности развития острой пневмонии у детей раннего возраста. Статистическая значимость созданной модели подтверждена Omnibus Test, диагностическая информативность оценена по данным ROC-кривой, которая подтвердила хорошее качество модели.

Выводы. На основании фракторного анализа выделены наиболее приоритетные предикторы развития острой пневмонии у детей раннего возраста, больных острой бронхолегочной патологией, которые в дальнейшем вошли в математическую модель прогноза вероятности развития указанного заболевания.

In recent years pneumonia which is the sixth most important reason of child mortality in the world continues to keep the relevance among diseases of respiratory organs [1]. It is one of the most frequent reasons of hospitalization of children up to 5 years old it demands timely diagnostics and the most effective treatment $[2,3]$. Influence of premorbid factors in development of acute pneumonia among children, such as the burdened obstetric and gynecologic anamnesis, pathology of the perinatal and intranatal periods, early artificial feeding is of great importance that can act as risk factor for most of severe diseases and a possible lethal outcome $[4,5]$. It is necessary to notice that factors which are not connected directly with development of the disease or its activator, but which are capable to worsen the course of a disease have no less influence on development of pneumonia.

It is known that the epithelium of respiratory tracts produces a number of protective factors - antimicrobic peptides among which cathelicidin LL-37 has the greatest protective properties, lactoferrin and hBPI $[43,44]$. Importance of value of antimicrobic peptides is beyond their classical local antimicrobic activity, their broad biological influence shows that these effector proteins provide communication between a congenital and adaptive immunity $[45,46]$. It does not raise doubts that the acquired defects of synthesis of antimicrobic peptides, especially against the background of deficiency of vitamin D promote increase in sensitivity to an infection and colonization conditionally by pathogenic microflora which promotes more severe disease and development of bacterial complications [47].

The predictive importance of both endogenous and exogenous risk factors of development of sharp pneumonia in children of early age, their influence on the nature of a course of a disease and its consequences are ambiguous, which demands additional studying.

\section{Purpose}

The purpose of this study was definition of influence of the modified factors in development of acute pneumonia in children of early age and development of a method of prognostication of disease development.

\section{Materials and methods}

Respect for ethical aspects. The 89 children with acute bronchopulmonary pathology among whom there are 47 children with acute bacterial bronchitis and 42 children with acute community-acquired pneumonia entered into group of observation (whose average age was $1.3 \pm 0.2$ years). Verification of the diagnosis was carried out according to clinical protocols of diagnostics and treatment of an acute bronchitis and acute pneumonia at children $[7,8]$. The assessment of the severity of the condition of patients was carried out in the first 24 hours from the moment of the admission to the hospital, in children with an acute bronchitis according to ABSS scale and in children with an acute pneumonia according to criteria of PRESS scale $[9,10]$.

Methods. Microbiological inspection of material of smears from a nasopharynx of the children with acute inflammatory bronchopulmonary pathology was conducted to purpose of antibacterial therapy, in the bacteriological COMPACT VITEK 2 analyzer (BioMérieux, France) with use of the software of AES: Global CLSI-based Phenotypic,

For the assessment of risk development of acute pneumonia in children of early age calculation of the relative risk $(R R)$ in tables of associativity $2 \times 2$, with determination of $95 \%$ of confidence intervals $(95 \% \mathrm{Cl}$ ) was carried out. Informative signs with $\mathrm{RR}$ value more than 1.0 were referred to number of the most significant factors. For the analysis of influence of risk factors of pneumonia development in children of early age with acute inflammatory bronchopulmonary pathology, we analyzed the obstetric and gynecologic anamnesis of mothers, pathology of perinatal and neonatal periods, the nature of feeding of children of the first year. Also data of the anamnesis of a disease taking into account hospitalization term in a hospital and terms of purpose of antibacterial therapy were considered. By means of an enzyme immunoassay we examined the serum content of 25-hydroxyvitamin $\mathrm{D}(25(\mathrm{OH}) \mathrm{D})$, human bactericidal/ permeability-increasing protein (hBPI), cathelicidin LL-37, lactoferrin. The results of researches of these peptides are published in the previous works $[48,49]$.

Reliability of data and statistical analysis. The mathematical analysis and statistical data processing were 
carried out with use of the licensed Statistica 13.0 software package (StatSoft Inc., №JPZ8041382130ARCN10-J). For the purpose of identification of factors which are most connected with development of acute pneumonia factor analysis was used. For definition of factorial loading of the studied indicators the Spearman correlation is chosen. The most meaningful factors in model investigated by means of criterion of "scree" and Kaiser criterion. For sampling rates with high factor loadings of the complex (more than 0.7 ) the method of orthogonal rotation VARIMAX was used. The analysis with use of rotation of VARIMAX is made taking into account results of the initial analysis and using the variance for describing main component data array [11].

For forecasting of probability of development of an acute pneumonia the equation of logistic regression was used:

$$
p=1 /(1+\exp (-z))
$$

де $z=a 0+a 1 \times x 1+a 2 \times x 2+\ldots+a n \times x n$;

$\mathrm{x} 1, \ldots, \mathrm{xn}-$ independent variables, $\mathrm{a} 0, \ldots$, an - index of regression ${ }^{2}$

If the calculated $p$ value equaled 0.5 or more, then this patient was assigned to a group of children with the largest probability of development of pneumonia. The quality of the constructed model was estimated on their sensitivity and specificity [12]. Statistical significance of the model was evaluated for Omnibus Test (universal coefficient test) and categorical predictor validity of the test.

For identification of factors which most degree are connected with risk of development of acute pneumonia in children of early age, the method of a genetic algorithm was used [13]. Determination of quality of the received model of forecasting was carried out by means of the ROC-analysis and an indicator of AUC - a numeral index of the area under a ROC-curve [14]. For the assessment of the discriminating ability of model the Gini index was calculated by the formula:

$$
\text { Gini }=2 \times(A U C-1) \times 100[15] .
$$

The interrelation between separate factors was estimated by means of coefficient of pair correlation of Pearson.

\section{Results}

The conducted analysis of a microbiological culture from nasopharynx of children with acute inflammatory bronchopulmonary pathology showed that in the group of children with acute pneumonia in $64.4 \%$ (21 cases) the etiologic factor is the Streptococcus pneumoniae. Almost half less common gram-negative pathogen is Haemophillus influenza - 28.5\% (12 cases). The $4.7 \%$ ( 2 cases) it was Klebsiella pneumonia, in 1 case (2.4\%) occurred cryptogenic pathogen.

For identification of the most informative criteria influencing the development of pneumonia in children of early age with acute inflammatory bronchopulmonary pathology factor analysis which allowed to allocate the main factors of risk of development of the specified pathology was conducted.
Table 1. The size of general dispersion of variables, that is presented by the first 5 factors

\begin{tabular}{|l|l|l|l|}
\hline The factor & Eigenvalues & $\%$ of total dispersion & The cumulative \% \\
\hline 1 & 2.251 & 18.760 & 18.760 \\
\hline 2 & 1.924 & 16.040 & 34.801 \\
\hline 3 & 1.651 & 13.765 & 48.566 \\
\hline 4 & 1.501 & 12.514 & 61.081 \\
\hline 5 & 1.255 & 10.461 & 71.542 \\
\hline
\end{tabular}

Table 2. Design of factorial loads of indicators that were studied, for the children

\begin{tabular}{|c|c|c|c|c|c|}
\hline \multirow[t]{2}{*}{ The indicators } & \multicolumn{5}{|c|}{ The factor loadings } \\
\hline & 1 & 2 & 3 & 4 & 5 \\
\hline The low birth weight & & -0.793 & & & \\
\hline The hospitalization time & -0.918 & & & & \\
\hline The late starting prescription of antibacterial treatment & -0.911 & & & & \\
\hline The severity of disease & & & & & -0.770 \\
\hline The character of feeding & & -0.702 & & & \\
\hline Vitamin D & & & & 0.883 & \\
\hline Lactoferrin & & & & 0.717 & \\
\hline Cathelicidin LL-37 & & & -0.810 & & \\
\hline hBPI & & & -0.795 & & \\
\hline Hemoglobin level & & & & & 0.841 \\
\hline The sex of child & & -0.745 & & & \\
\hline
\end{tabular}
of early age with acute bronchopulmonary pathology

23 significant factors of development of acute pneumonia for the children of early age were selected by us, among them there were such modified factors as the course data of perinatal period, character of nature feeding of child of the first year, data of anamnesis and severity of the disease, level of haemoglobin in peripheral blood, maintenance in the blood serum of vitamin $D$ and antimicrobial peptids (lactoferrin, LL-37, hBPI) and such not modified factor, as sex of child.

Factor analysis was conducted with the use of rotation of VARIMAX taking into account the results of initial analysis and allowed to determine possible to identify five main components (Table 1). Actually the number of components exceeded 1.0, and their total contribution to general variation was $71.5 \%$. It specified on that these factors determine basic part of predictors of development of acute pneumonia for children from the groups of observation (Table 1).

On the next stage by means of method of main components the matrix of the factor loading was determined (Table 2).

According to the obtained data, the $1^{\text {st }}$ factor which described $18.7 \%$ of the total variations, had a high degree of loading, which includes the indexes of term of hospitalization (factor loading - 0.918, RR 1.94, $95 \%$ Cl 1.30-2.92) and the late starting prescription of antibacterial treatment (factor loading - 0.911, RR 1.64, $95 \% \mathrm{Cl} 1.07-2.53$ ).

The data we received look logically, if to take into account that the late appeal of patients seeking care and ill-timed setting of antibacterial therapy on the pre-hospital stage come forward to one of reasons of severe course of the disease $[16,29]$.

It is known at the same time, that the timely set of diagnosis and early rational etiotropic treatment are the predictors of favourable end of pneumonia [16]. 
Table 3. The correlation matrix of predictors that have influence on development of acute pneumonia in children with acute bronchopulmonary pathology

\begin{tabular}{|c|c|c|c|c|c|c|c|c|c|c|c|}
\hline № & The indicators & 1 & 2 & 3 & 4 & 5 & 6 & 7 & 8 & 9 & 10 \\
\hline 1 & Vitamin D & 1.00 & & & & & & & & & \\
\hline 2 & Cathelicidin LL-37 & 0.26 & 1.00 & & & & & & & & \\
\hline 3 & Lactoferrin & $0.44^{*}$ & -0.25 & 1.00 & & & & & & & \\
\hline 4 & hBPI & $0.47^{*}$ & 0.04 & -0.13 & 1.00 & & & & & & \\
\hline 5 & Hemoglobin level & 0.05 & -0.07 & 0.05 & -0.09 & 1.00 & & & & & \\
\hline 6 & Hospitalization time & $0.36^{*}$ & -0.24 & $0.44^{*}$ & -0.31 & 0.14 & 1.00 & & & & \\
\hline 7 & The severity of disease & -0.3 & $-0.47^{*}$ & 0.29 & $-0.43^{*}$ & -0.01 & 0.35 & 1.00 & & & \\
\hline 8 & The character of feeding & 0.18 & 0.06 & -0.07 & 0.16 & -0.03 & -0.11 & -0.11 & 1.00 & & \\
\hline 9 & The low birth weight & -0.12 & -0.07 & 0.08 & 0.03 & 0.27 & -0.13 & 0.17 & 0.21 & 1.00 & \\
\hline 10 & $\begin{array}{l}\text { The late starting prescription } \\
\text { of antibacterial treatment }\end{array}$ & 0.27 & -0.29 & 0.04 & 0.03 & -0.05 & $0.44^{*}$ & 0.57 & -0.18 & 0.03 & 1.00 \\
\hline
\end{tabular}

Reliability degree: * $-\mathrm{P}<0.05$.

Table 4. The indicators which are included in the prognostic model of the probability of acute pneumonia developing in children of early age

\begin{tabular}{|c|c|c|c|c|c|}
\hline The indicators & The level of indicators & The regression coefficient & The standard error & The Wald Criterion & $\mathbf{P}$ \\
\hline The level of vitamin $D$ & $\mathrm{X} 1$ & -0.025 & 0.011 & 5.627 & 0.018 \\
\hline Lactoferrin & $\mathrm{X} 2$ & 0.230 & 0.108 & 4.519 & 0.034 \\
\hline hBPI & X3 & 0.001 & 0.001 & 7.660 & 0.006 \\
\hline Hospitalization time & $\mathrm{X} 4$ & 0.391 & 0.162 & 5.807 & 0.016 \\
\hline \multirow[t]{2}{*}{ The day of prescription of antibacterial treatment } & X5 & 0.297 & 0.167 & 3.158 & 0.076 \\
\hline & Constant & -3.997 & 1.401 & 8.138 & 0.004 \\
\hline
\end{tabular}

The structure of the second factor which described $16.0 \%$ of a total variation included data of the perinatal period, a sex of the child and the nature of feeding in the first year (factorial loadings -0.793 , RR $3.10,95 \%$ Cl 1.85-5.19; -0.745, RR 1.79, $95 \%$ Cl 1.07-3.04 and -0.702 , RR 1.64, $95 \%$ Cl 1.07-2.43 respectively). Population prospective research showed that the risk of origin of lower respiratory tract infections in children aged up to 6 months receiving completely natural feeding, was lower, than in group of the children who were on the mixed feeding since 4 months and in comparison with children receiving only milk mixes [17]. Also such unmodified factor as the sex of the child mattered, data of foreign researchers confirm that almost 2 times more frequently acute episodes of pneumonia occur among boys, especially in the age of 1 year $[10,18]$.

The third factor, described as "antimicrobial", was presented by the indexes of maintenance in serum blood cathelicidin (factor loading 0.810, RR 1.80, $95 \%$ Cl 1.25-2.62) and hBPI (factor loading 0.795, RR 1.75, $95 \% \mathrm{Cl} 1.06-2.88$ ) with total variation of 13.7. Data of Jahani S (2015) show that in the conditions of deficit of $\mathrm{hBPI}$ there is a decline of expression of cathelicidine LL37, lactoferrin and lysozyme, which, in turn, results in more considerable colonization of pathogenic microflora and can result in more severe course of the disease [19].

With a total variation of $12.5 \%$ there is the level of vitamin $D$ and lactoferrin in the blood serum (factorial loading 0.883, RR 1.84, $95 \%$ Cl 1.16-2.93 and 0.717, RR 3.98, $95 \% \mathrm{Cl} 2.35-6.75$ respectively). Today in literature many proofs of influence of vitamin D on the immune system are saved up. According to M. Mamani et al. (2017) children aged till 18 years with heavy deficiency of vitamin $D$ are 4.16 times more inclined to development of community-acquired pneumonia in comparison with peers with higher level of the specified vitamin [1]. Wayse et al. (2004) in his study of 150 children under 5 years showed that that one of the factors associated with more severe course of acute inflammatory infections of the lower respiratory tract was serum $25(\mathrm{OH}) \mathrm{D}$ less than $10 \mathrm{ng} / \mathrm{ml}(\mathrm{OR}=11)$ [6]. Also, one more marker that reflects reactivity of an organism to inflammatory processes and acts as an index of activity of the T-cellular link of immunity is lactoferrin [20]. Data from M. P. Rogan et al (2006) and Singh PK (2000) confirm the synergistic effect of bacterial neutralization of lactoferrin with other immune proteins, in particular SLPI, LL-37 and vitamin D [21,22]. That is, it is possible to assume that insufficient activation of lactoferrin in inflammatory process will lead bronchopulmonary system to more severe disease and development of complications, especially against the background of deficiency of other markers of protection.

To the fifth factor hemoglobin level indicators in peripheral blood and severity of the disease (factorial loading 0.841, RR 2.19, $95 \%$ Cl 1.25-3.84 and -0.770, RR 1.75, $95 \% \mathrm{Cl} 1.06-2.88$ respectively) with a total variation of $10.4 \%$ entered. It is known that anemia has negative impact on development of pneumonia and more severe disease is the reason [23]. The risk of development of pneumonia in children with anemia increases approximately by four times in comparison with children who have no anemic syndrome [24]. Anemia and low oxygen saturation of hemoglobin promote reduction of oxygen delivery to tissues. Patients with anemia suffer from hypoxia during pneumonia more, than patients without anemia $[25,26]$.

For specification of structural interrelations of the factors which are most influencing development of pneumonia in the children with acute diseases of bronchopulmonary system we carried out correlation analysis of variables. By results of the analysis of a matrix of a rank correlation in the group of children with acute bronchopulmonary diseases, existence of certain interrelations between prenatal, anamnestic and immune factors was set (Table 3). 
As can be seen from data of table 3 , meaningful cross correlation connections were set between maintenance of vitamin $D$ in the blood serum and level of antimicrobial peptids (lactoferrin, $r=0.44, P<0.05$ and $h B P I, r=0.47$, $P<0.05)$, that looked fully logically, its well-proven in fact, that the vitamin of $D$ has direct influence on the expression of antimicrobial peptides, and its deficit worsens local protective reactions [15]. According to our data intercommunication was also between the terms of setting of antibacterial therapy and level of vitamin $D(r=0.57, P<0.05)$, lactoferrin $(r=0.40, P<0.05)$ and $h B P I(r=0.38, P<0.05)$ in the blood serum. The obtained data look logical, if to take into account circumstance that antimicrobial peptides together with antibacterial preparations can show a synergistic effect in regard to pathogenic causative agents and promote effictive etiotropic therapy [27,28].

The next stage of the work was creation of mathematical model of probability of development of acute pneumonia for the children of early age with the use of method of logistic regression on the basis of estimation of influence of the distinguished most meaningful modified risk of development of the indicated pathology factors among children with acute inflammatory bronchopulmonary pathology (Table 4).

As a result of the conducted analysis 5 factor signs were selected: the level of vitamin $D(X 1)$, lactoferrin (X2) and hBPI in the blood serum (X3), day of hospitalization (X4) and terms of setting of antibacterial therapy (X5) from the beginning of disease.

The logistic regression equation of probability of acute pneumonia development in children with acute bronchopulmonary pathology looked like this: $P=1$ / $(1+\exp (-(-3.997-0.025 \times \mathrm{X} 1+0.230 \times \mathrm{X} 2+0.001 \times$ $\mathrm{X} 3+0.391 \times \mathrm{X} 4+0.297 \times \mathrm{X} 5)))$.

When obtaining the value of $\mathrm{P} \geq 0.5$ - development of acute pneumonia is predicted.

In Table 5 there is classification ability of model that was determined from data of scientific selection and made up $79.3 \%$. The statistical significance of the model was confirmed by the universal criteria model coefficients (Omnibus Test) $-\chi 2=34.553 ; \mathrm{df}=5 ; \mathrm{P}=0.001$. The sensitivity of model appeared equal $78.3 \%$, and specificity $-80.5 \%$. The coefficient of predictive categorial validity of the test made $r=0.58$.

The diagnostic informational content of the received model was estimated on display data from the ROC-curve (receiver-operator characteristic curve) (Fig. 1).

The area under a ROC-curve (AUC), that displays a representation of a logistic regression equation, is equal to 0.85 , the Gini index was $70 \%$, that characterizes a good quality model. The positive predictive values (PPV) of the results were $81 \%$ and negative predictive values (NPV) $-76 \%$.

Thus, the possible influence on the indicated factors of patients, stated in equalization, will give an opportunity to prevent development of an acute pneumonia in the indicated group of children.

\section{Discussion}

The results of the conducted factor analysis are of interest to definition of key predictors for prognostication of
Table 5. The classification table of the calculated probability of development of acute pneumonia in children of early age

\begin{tabular}{l|l|l|l} 
& \multicolumn{2}{|l|}{ Predicted by the regression equation } & The match \\
\cline { 2 - 3 } & $\begin{array}{l}\text { The acute } \\
\text { pneumonia }\end{array}$ & $\begin{array}{l}\text { The acute bacterial } \\
\text { bronchitis }\end{array}$ & \\
\hline The acute pneumonia & 36 & 10 & $78.3 \%$ \\
\hline $\begin{array}{l}\text { The acute bacterial } \\
\text { bronchitis }\end{array}$ & 8 & 33 & $80.5 \%$ \\
\hline Total & & $79.3 \%$ \\
\hline
\end{tabular}

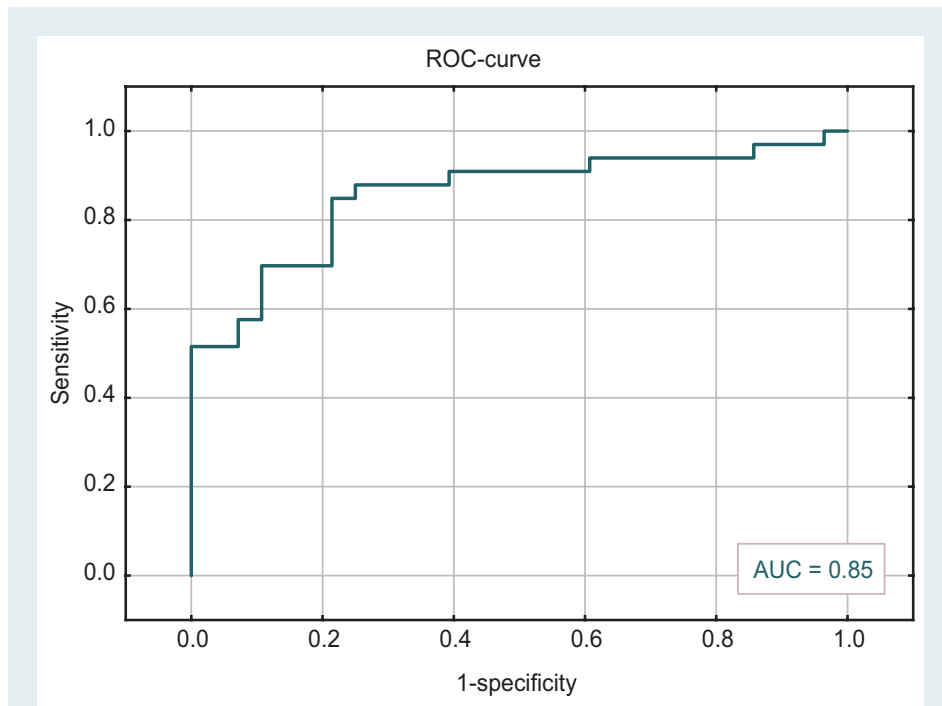

Fig. 1. The ROC-curve of the equation of logistic regression of prognostic development of acute pneumonia in children of early age.

possibility of acute pneumonia development in children of early age with inflammatory diseases of bronchopulmonary system. The method of binary logistic regression allowed to identify predictors that were not used in earlier mathematical models and that allowed with the largest probability to predict development of acute pneumonia.

Predictors that are directly not connected with development of acute pneumonia are of special interest, but have an impact development of local inflammation in a bronchopulmonary system. In particular, vitamin D role as a key marker of inflammation and a predictor of severity of inflammatory process in a respiratory tract is confirmed with numerous researches. So, J. D. Chalmers et al. in the work revealed a feedforward between the lowered level of 25-OHD in blood serum and the chronic course of inflammatory respiratory diseases. [30]. In other research that was conducted with participation of children of early age with acute infection of respiratory tracts associative relationship between the level of vitamin $D$ and 7 -fold risk of development of acute disease was also revealed [31]. These and other scientific works led to a new era of understanding of value of vitamin $\mathrm{D}$ in a pathogeny of an immune response on colonization by bacterial pathogens of a respiratory tract.

The interrelation of vitamin $\mathrm{D}$ with such antimicrobic peptides as lactoferrin and hBPI attracts attention. Direct influence of vitamin $D$ on synthesis of antimicrobic peptides, that are the primary agents in antimicrobial protection of a respiratory epithelium, is proved [32]. In 
particular, in a number of researches correlation relationships were found between levels of lactoferrin and vitamin $D$ for patients with chronic diseases of a bronchopulmonary system and also their synergy action against gram-negative bacteria [33-35]. Also, along with vitamin $\mathrm{D}, \mathrm{hBPI}$ peptide has potent endotoxin neutralizing effect and antimicrobial activity, and it is abundantly expressed in the respiratory tracts $[36,37]$. This antimicrobic peptide has direct cytotoxic action not only in relation to gram-negative bacteria, but also to some strains of gram-positive bacteria [38]. Today there is no clear understanding of a role of the specified peptide in the pathogenesis of development of local inflammation in a respiratory tract, however its influence on mucociliary clearance and also its direct participation in a local immune response at the majority of pulmonary diseases is proved. [39,40].

Thus, most scientific researches confirm an important role of the specified peptides in regulation of inflammatory reactions to pathogens $[41,42]$. And though the questions concerning mechanisms of immunomodulatory action are not absolutely studied yet, the general ability of antimicrobial peptides to participate in preventing of bacterial colonization and also a direct role in inflammation mechanisms is proved [33].

Thus, the mathematical model created by us allows defining with high probability group of patients with high risk of development of pneumonia in inflammatory pathology of a bronchopulmonary system. It will provide the direction on deeper additional examination for the purpose of prevention of complications and a lethal outcome.

\section{Conclusions}

1. The conducted factor analysis allowed to define predictors of risk of acute pneumonia development in children of early age on the basis of which predictive model of pathological process forming was created. The most priority contribution to the development of acute pneumonia belonged to the data in the perinatal period, the child's sex, nature of infant feeding in the first year of life, data history and severity of the disease, hemoglobin levels in the peripheral blood serum levels of vitamin $\mathrm{D}$, and antimicrobial peptides (lactoferrin, LL-37, hBPI).

2. The established logistic regression model has good predictive efficiency and confirms the role of the level of vitamin D (RR 1.84, $95 \% \mathrm{Cl} 1.16-2.93)$, lactoferrin (RR $3.98,95 \% \mathrm{Cl} 2.35-6.75)$ and hBPI (RR 1.75, $95 \% \mathrm{Cl}$ 1.06-2.88) in blood serum and also the late request of patients for medical care (RR 1.94, $95 \% \mathrm{Cl} 1.30-2.92)$ and late appointment of antibacterial therapy (RR 1.64, $95 \% \mathrm{Cl} 1.07-2.53$ ) in the occurrence of acute pneumonia in children.

3. The received results allow to determine the probability of development of pneumonia in the children of early age with a disease of acute respiratory infection with probability to $79.3 \%$ by individual values of the established risk factors.

Prospects further researches. The obtained results require additional study in further, which in turn will contribute to improving the quality of prevention of bacterial respiratory diseases in young children.
Conflicts of interest: authors have no conflict of interest to declare. Конфмікт інтересів: віАсутній.

Надійшла Ао реАакції / Received: 26.12.2018

Після Аоопрацювання / Revised: 05.04.2019

Прийнято Ао Аруку / Accepted: 11.04.2019

Information about authors:

Lezhenko H. O., MD, PhD, DSc, Professor, Head of the Department of Hospital Pediatry, Zaporizhzhia State Medical University, Ukraine.

Abramov A. V., MD, PhD, DSc, Professor, Department of Pathologic Physiology, Zaporizhzhia State Medical University, Ukraine. Krainia H. V., MD, Assistant of the Department of Hospital Pediatry, Zaporizhzhia State Medical University, Ukraine.

\section{Відомості про авторів:}

Меженко Г. О., А-р меА. наук, професор, зав. каф. госпітальної педіатрії, Запорізький Аержавний медичний університет, Україна. Абрамов А. В., А-р меА. наук, професор каф. патологічної фізіології, Запорізький Аержавний медичний університет, україна.

Крайня Г. В., асистент каф. госпітальної педіатрії, Запорізький Аержавний медичний університет, Україна.

\section{Сведения об авторах:}

Леженко Г. А., А-р меА. наук, профессор, зав. каф. госпитальной педиатрии, Запорожский государственный меАицинский университет, Украина.

Абрамов А. В., А-р меА. наук, профессор каф. патологической физиологии, Запорожский госуАарственный медицинский университет, Украина.

Крайняя А. В., ассистент каф. госпитальной педиатрии,

Запорожский государственный медицинский университет, Украина.

\section{References}

[1] Mamani, M., Muceli, N., Ghasemi Basir, H. R., Vasheghani, M., \& Poorolajal, J. (2017). Association between serum concentration of 25-hydroxyvitamin D and community-acquired pneumonia: a case-control study. International journal of general medicine., 10, 423-429. doi: 10.2147/IJGM.S149049

[2] Wingerter, S. L., Bachur, R. G., Monuteaux, M. C., \& Neuman, M. I. (2012). Application of the world health organization criteria to predict radiographic pneumonia in a US-based pediatric emergency department. The Pediatric infectious disease journal., 31(6), 561-564. doi: 10.1097/ INF.0b013e31824da716

[3] El-Sayed, W. A., \& Aamer, E. R. (2017). Serum 25 oh vitamin d in children with bacterial pneumonia. Zagazig University Medical Journal., 21(1), 1-8. doi: 10.21608/ZUMJ.2015.4466

[4] Le Saux, N., \& Robinson, J. L. (2011). CPS Infectious Diseases and Immunization Committee. Pneumonia in healthy Canadian children and youth: Practice points for management. Paediatr Child Health 16(7), 417-20.

[5] Van deer Meer, V., Neven, A. K., van den Broek, P. J., \& Assendelft, W. J. (2005). Diagnostic value of C-reactive protein in infections of the lower respiratory tract: systematic review. BMJ., 331(7507), 26.

[6] Wayse, V., Yousafzai, A., Mogale, K., \& Filteau, S. (2004). Association of subclinical vitamin $D$ deficiency with severe acute lower respiratory infection in Indian children under 5 y. Eur J Clin Nutr., 58(4), 563-567. doi: 10.1038/sj.ejcn.1601845

[7] Nakaz Ministerstva okhorony zdorovya Ukrainy «Protokol likuvannia ditei z hostrymy bronhitamy» 31 hrudnia 2005 roku №18 [Law of Ukraine Protocol for the treatment of children with acute bronchitis from December 31, 2005, №18]. Retrieved from: zakon.rada.gov.ua [in Ukrainian].

[8] Nakaz Ministerstva okhorony zdorovya Ukrainy «Protokol likuvannia ditei z hostrymy bronhitamy» 31 hrudnia 2005 roku №18 [Law of Ukraine Protocol for the treatment of children with acute bronchitis from December 31, 2005, №18]. Retrieved from: zakon.rada.gov.ua [in Ukrainian].

[9] Mwachari, C., Nduba, V., Nguti, R., Park, D. R., Sanguli, L., \& Cohen, C. R. (2007). Validation of a new clinical scoring system for acute bronchitis. Int J Tuberc Lung Dis., 11(11), 1253-9.

[10] Yumiko, M., Kazuko, S., \& Asako, N. (2015). Pediatric Respiratory Severity Score (PRESS) for Respiratory Tract Infections in Children. Austin Virol and Retrovirology., 2(1), 1009. 
[11] Tikhomirov, N. P., Tikhomirova, T. M., \& Ushmaev, O. S. (2011). Metody e'konometriki i mnogomernogo statisticheskogo analiza [Methods of econometrics and multidimensional statistical analysis]. Moscow: Ekonomika [in Russian].

[12] Lyakh, Yu. E., \& Gur'yanov, V. G. (2012). Matematicheskoe modelirovanie pri reshenii zadach klassifikacii v biomedicine [Mathematical modeling in solving problems of classification in biomedicine]. Ukrainskyi zhurnal telemedytsyny ta medychnoi telematyky, 10(2), 69-76. [in Russian].

[13] Petri, A., \& Sebin, K. (2003). Naglyadnaya statistika v medicine [Visual statistics in medicine]. Moscow: GE'OTAR-Media, [in Russian]

[14] Sorokin, A. S. (2014). K voprosu validacii modeli logisticheskoj regressii $\checkmark$ kreditnom skoringe [On the question of validation logistic regression model in credit scoring]. Naukovedenie, 2(21), 81. [in Russian].

[15] Meyz, E. (2008). Rukovodstvo po kreditnomu skoringu [Credit Scoring Guide]. Minsk: Grevtsov Pablisher. [in Russian].

[16] Grigoryeva, E. V., \& Efremova, O. K. (2010). Analiz kachestva vedeniya bol'nykh s vnebol'nichnoj pnevmoniej v usloviyakh terapevticheskogo otdeleniya gorodskoj bol'nicy [Analysis of the quality of keeping of patients with community-acquired pneumonia in conditions of therapeutic ward of municipal hospital]. Acta Biomedica Scientifica, 2(72), 129-131. [in Russian].

[17] Bush, A., Carlsen, R. H., \& Zach, M. S. (2002). Growing up with lung disease: the lung in transition to adult life. ERSM, 189-213.

[18] Mazur, L. I., Kulagina, V. V., Cherkasova, S. V. (2010). Osobennosti diagnostiki i techeniya vnebol'nichnoj pnevmonii u detej [Features of diagnosis and course of community-acquired pneumonia in children]. Pediatriya. Zhurnal im. G.N. Speranskogo, 89(4), 154-160. [in Russian].

[19] Jahani, S., Shakiba, A., \& Jahani, L. (2015). The Antimicrobial Effect of Lactoferrin on Gram-Negative and Gram-Positive Bacteria. International Journal of Infection, 2(3), e27954. doi: 10.17795/iji27594

[20] Kudryasheva, I. A., Galimzyanov, Kh. M., Polunina, O. S., \& Shelepova, T. N. (2008). Immunokhimicheskoe testirovanie laktoferrina pri vnebol'nichnoj pnevmonii u pozhilykh bol'nykh [Immunochemical testing of lactoferrin in community-acquired pneumonia in elderly patients]. Fundamental'nye issledovaniya, 2, 34-35. [in Russian]

[21] Rogan, M. P., Geraghty, P., Greene, C. M., O’Neill, S. J., Taggart, C. C., \& McElvaney, N. G. (2006). Antimicrobial proteins and polypeptides in pulmonary innate defence. Respiratory research, 7(1), 29.

[22] Singh, P. K., Tack, B. F., McCray, P. B. Jr., \& Welsh, M. J. (2000). Synergistic and additive killing by antimicrobial factors found in human airway surface liquid. Am J Physiol Lung Cell Mol Physiol, 279(5), L799-805.

[23] Spence, R. K. (2007) Medical and economic impact of anemia in hospitalized patients. Am. J. Hlth Syst. Pharm., 64(16 Suppl 11), S3-10. doi: 10.2146/ajhp070244

[24] Rashad, M. M., Fayed, S. M., \& El-Hag, A. M. K. (2015). Iron-deficiency anemia as a risk factor for pneumonia in children. Benha Medical Journal, 32(2), 96-100.

[25] Nagel, R. E., \& Jaffe, E. R. (2001). Disorders of Hemoglobin: Genetics, Pathophysiology, and Clinical Management. New York: Cambridge University Press, 1214-33.

[26] Budnevsky, A. V., Esaulenko, I. E., Ovsyannikov Evgeniy, S., Labzhaniya, N. B., Voronina, E. V., \& Chernov, A. V. (2016). Anemicheskij sindrom u bol'nykh vnebol'nichnoj pnevmoniej [Anemic syndrome in patients with communal non-patient pneumonia]. Klinicheskaya medicina, 94(1), 56-60. [in Russian].

[27] Wu, X., Li, Z., Li, X., Tian, Y., Fan, Y., Yu, C., et al. (2017). Synergistic effects of antimicrobial peptide DP7 combined with antibiotics against multidrug-resistant bacteria. Drug design, development and therapy, 11, 939-946. doi: 10.2147/DDDT.S107195

[28] Feng, Q., Huang, Y., Chen, M., Li, G., \& Chen, Y. (2015). Functional synergy of a-helical antimicrobial peptides and traditional antibiotics against Gram-negative and Gram-positive bacteria in vitro and in vivo. European Journal of Clinical Microbiology \& Infectious Diseases, 34(1), 197-204. doi: 10.1007/s10096-014-2219-3

[29] Huchon, G., Woodhead, M., Gialdroni-Grassi, G., et al. (2010). Guidelines for management of adult community- acquired lower respiratory tract infections. Eur. Resp. J.,11, 986-991.

[30] Chalmers, J. D., McHugh, B. J., Docherty, C., Govan, J. R., \& Hill, A. T. (2013). Vitamin-D deficiency is associated with chronic bacterial colonisation and disease severity in bronchiectasis. Thorax, 68(1), 39-47. doi: 10.1136/thoraxjnl-2012-202125

[31] Laaksi, I., Ruohola, J. P., Mattila, V., Auvinen, A., Ylikomi, T., \& Pihlajamäki, H. (2010). Vitamin D supplementation for the prevention of acute respiratory tract infection: a randomized, double-blinded trial among young Finnish men. The Journal of infectious diseases, 202(5), 809-814. doi: 10.1086/654881

[32] Lai, Y., \& Gallo, R. L. (2009). AMPed up immunity: how antimicrobial peptides have multiple roles in immune defense. Trends Immunol, 30(3), 131-41. doi: 10.1016/j.t.2008.12.003

[33] Parker, D., \& Prince, A. (2011). Innate immunity in the respiratory epithelium. American journal of respiratory cell and molecular biology, 45(2), 189-201. doi: 10.1165/rcmb.2011-0011RT
[34] Sagel, S. D., Sontag, M. K., \& Accurso, F. J. (2009). Relationship between antimicrobial proteins and airway inflammation and infection in cystic fibrosis. Pediatr Pulmonol, 44(4), 402-409. doi: 10.1002/ ppul.21028

[35] Sim, S. H., Liu, Y., Wang, D., Novem, V., Sivalingam, S. P., Thong, T. W., et al. (2009). Innate immune responses of pulmonary epithelial cells to Burkholderia pseudomallei infection. PLoS ONE, 4(10), e7308. doi: 10.1371 /journal.pone.0007308

[36] Chu, H. W., Gally, F., Thaikoottathil, J., Janssen-Heininger, Y. M. Wu, Q., Zhang, G., et al. (2010). SPLUNC1 regulation in airway epithelial cells: role of toll-like receptor 2 signaling. Respir Res, 11, 155. doi: 10.1186/1465-9921-11-155

[37] Britto, C. J., \& Cohn, L. (2015). Bactericidal/Permeability-Increasing Protein Fold-Containing Family Member A1 in Airway Host Protection and Respiratory Disease. American journal of respiratory cell and molecular biology, 2015, 52(5), 525-534. doi: 10.1165/rcmb.2014-0297RT

[38] Canny, G., \& Levy, O. (2008) Bactericidal/permeability-increasing protein (BPI) and BPI homologs at mucosal sites. Trends in immunology, 29(11), 541-547. doi: 10.1016/j.it.2008.07.012

[39] Britto, C. J., Liu, Q., Curran, D. R., Patham, B., Dela Cruz, C. S., \& Cohn, L. (2013). Short palate, lung, and nasal epithelial clone-1 is a tightly regulated airway sensor in innate and adaptive immunity. $\mathrm{Am} \mathrm{J}$ Respir Cell Mol Biol, 48(6), 717-724. doi: 10.1165/rcmb.2012-00720C

[40] Liu, Y., Bartlett, J. A., Di, M. E., Bomberger, J. M., Chan, Y. R., Gakhar, L., et al. (2013). SPLUNC1/BPIFA1 contributes to pulmonary host defense against klebsiella pneumoniae respiratory infection. Am J Pathol, 182(5), 1519-1531. doi: 10.1016/j.ajpath.2013.01.050

[41] Coussens, A, Timms, P. M., Boucher, B. J., Venton, T. R., Ashcroft, A. T., Skolimowska, K. H., et al. (2009). 1a,25-dihydroxy1,25(OH)2D3 inhibits matrix metalloproteinases induced by Mycobacterium tuberculosis infection. Immunology, 127(4), 539-48. doi: 10.1111/j.13652567.2008.03024.x

[42] Di Rosa, M., Malaguarnera, M., Nicoletti, F., \& Malaguarnera, L. (2011). Vitamin D3: a helpful immuno-modulator. Immunology, 134(2), 123-139. doi: 10.1111/j.1365-2567.2011.03482.x

[43] Hancock, R. E. W., Haney, E. F., \& Gill, E. E. (2016). The immunology of host defence peptides: beyond antimicrobial activity. Nature Reviews Immunology, 16(5), 321-335. doi: 10.1038/nri.2016.29

[44] Wang, G. (2014). Human antimicrobial peptides and proteins. Pharmaceuticals, 7(5), 545-594. doi: 10.3390/ph7050545

[45] Guani-Guerra, E., Santos-Mendoza, T., Lugo-Reyes, S. O., \& Terán, L. M. (2010). Antimicrobial peptides: general overview and clinica implications in human health and disease. Clinical Immunology, 135(1), 1-11. doi: 10.1016/j.clim.2009.12.004

[46] Holzl, M. A., Hofer, J., Steinberger, P., Pfistershammer, K., \& Zlabinger, G. J. (2008). Host antimicrobial proteins as endogenous immunomodulators. Immunol Lett, 119(1-2), 4-11. doi: 10.1016/j. imlet.2008.05.003

[47] Auvynet, C. \& Rosenstein, Y. (2009). Multifunctional host defense peptides: antimicrobial peptides, the small yet big players in innate and adaptive immunity. The FEBS journal, 276(22), 6497-6508. doi: 10.1111/j.1742-4658.2009.07360.x

[48] Lezhenko, G. O., Pashkova, O. E., \& Kraynya, H. V. (2017). The place of endogenous antimicrobial peptides in the pathogenetic mechanisms of the development of community-acquired pneumonia caused by Streptococcus pneumoniae among infants. Childs health, 12(4), 459-464.

[49] Lezhenko, G. O., Pashkova, O. E., \& Krainia, G. V. (2017). Vmist antymikrobnykh peptydiv u ditei rannioho viku, khvorykh na hostryi bronkhit, zalezhno vid etiolohichnoho chynnyka [The content of antimicrobial peptides in young children with acute bronchitis, depending on the etiologic factor]. Zdorov'ye rebenka, 12(1), 6-12. [in Ukrainian]. 